\title{
NOVOBAROKO A ČESKÁ SOCHAŘSKÁ GENERACE DEVADESÁTÝCH LET 19. STOLETÍ
}

\author{
MARTINA BEZOUŠKOVÁ \\ Seminář pro dějiny umění Filozofické fakulty Univerzity Karlovy \\ bezouskova.m@email.cz
}

\begin{abstract}
Neo-Baroque and the Generation of Czech Sculptors of the 1890s

Second half of the 19th century saw a number of national attempts to revise the Baroque values. Czech Neo-Baroque sculpture represents a style-expressive tendency, which reflected this nationally motivated interest and at the same time became a response to the change of esthetic taste of the end of the century. The goal of this article is to introduce the generation of sculptures of 1890s who built on the works of Josef Václav Myslbek, František Bílek and Bohuslav Schnich and presented their Neo-Baroque pieces for public monument tenders or at Art Union exhibitions. Variable and unexplored Neo-Baroque, which can be found in pieces by many authors (Vilím Amort, Quido Kocián, Josef Strachovský, Stanislav Sucharda, Gustav Zoula etc.) helps to find the missing idealistic and stylistic links between key Czech sculptores whose work made way towards modern articulation of matter in the beginning of the 20th century.

Keywords: Neo-Baroque - Baroque revival -Sculpture - Josef Václav Myslbek - Art Union
\end{abstract}

Novobaroko je vícevrstevnaté a spletité. Může být vnímáno v obecném slova smyslu jako pomyslný začátek nového společenského směřování na poli vizuální kultury, nebo tradičněji jako jeden $\mathrm{z}$ historizujících slohů konce 19. století. ${ }^{1} \mathrm{~V}$ rámci českého sochařství v sobě zmíněné téma spojuje pochopení novobaroka coby stylově-expresivní tendence a zároveň docenění dlouho hanobeného barokního umění, jehož kouzlo bylo v evropském formátu objevováno především ve druhé polovině 19. století. Proces rehabilitace barokních hodnot probíhal pozvolna a umění 17. a 18. století, byt' užívané v rámci akademického curricula jako vzor, ${ }^{2}$ bylo ještě ve dvacátých i třicátých letech 20 . století zesměšňováno a označováno hanlivým způsobem. „Umění není nikdy barokní a baroko

1 Viz Martina Bezoušková, České novobarokní sochařství, dizertační práce Ústavu pro dějiny umění FF UK, Praha 2019. - Tento článek vznikl jako součást př́ípravy publikace Martina Bezoušková, České novobarokní sochařství. Jeden $z$ historizujících stylů 19. století, nebo predstupeň na cestě k modernosti? Praha 2021.

2 Již krátce po založení Společnosti vlasteneckých přátel umění (1796) byly vypisovány kresliřské soutěže. Mladí adepti v rámci zadání „zachytit veřejná díla“ kopírovali význačné malby i plastiky z umění 17. a 18. století. Vznikaly tak kreslířské záznamy Reinerových fresek z pražských kostelů nebo Brokoffova Saturna z náhrobku Václava Vratislava z Mitrovic. Uvědomování si bohatého barokního památkového fondu, popřípadě jeho studium skrze kresliřské skici a kopie, se stalo předstupněm vzorníků 
není nikdy uměnim" “3 poznamenal Benedetto Croce v roce 1924, v době, kdy Evropa už prošla historizující fází.

Rehabilitaci baroka na teoretické rovině pomohly úvahy objevující se v průběhu druhé poloviny 19. století. Již v roce 1883 se anonymní recenzent publikace Georga

Niemanna o vídeňské architektuře osmělil baroko, i přes „všechny poklesky a hříchy proti zdravému vkusu“, doporučit ke studiu a možnému následování. ${ }^{4}$ Nelze opomenout ani ideologicky podbarvené názory Alberta Ilga a Cornelia Gurlitta, kteří v oživených barokních hodnotách spatřovali nástroj reprezentace. Zatímco Ilg se domníval, že rakouský národ by měl znovu oživit slavné časy, kdy baroko šlo ruku v ruce s rozkvětem habsburské dynastie, Gurlittova reakce se nedokázala zbavit zmínek o nadřazenosti umění německé provenience. ${ }^{5}$ Jejich názory se staly ukazatelem k nalezení abstraktního systému v pojetí Heinricha Wölfflina, který chtěl objasnit stylové principy baroka. Nejpodstatnější charakteristiku barokního principu proto Wölfflin vtělil do představy vracejících se forem, které se podle jeho názoru uplatnily ve všech stylových epochách západního umění a opakují se v jednotlivých fázích s pravidelnou periodicitou. ${ }^{6}$ Své myšlenky ohledně pozice baroka rozvinul Wölfflin do systematičtější podoby v práci Základní pojmy dějin umění (1915). Zde představil své antitetické dvojice - obecné formální znaky dvou protichůdných stylových modi̊, klasického a neklasického. Jejich porovnání umožňuje na první pohled snadné stylové analýzy nejen napřič epochami, ale rovněž v rámci uměleckých odvětví. Snaha o aplikování Wolfflinova systému na sochařství první poloviny 19. století (zastupující kategorii „klasické“) a druhé poloviny 19. století (pro kategorii „neklasické“), která by demonstrovala stylovou proměnu konce století, ovšem poukazuje, že se nejedná o př́stup poukazující na absolutní hodnoty obou základů (klasického i neklasického). Wölfflinovy pojmy související s neklasickým modem - malířskost, hloubka, otevřená (atektonická) forma, jednota a nejasnost - tak sice zdánlivě jednoduše vedou k nalezení barokního principu v sochařství druhé poloviny 19. století, Wölfflinovo rozdělení ale nestačí ani k prokázání jeho „refrénové podstaty“, natož k vytyčení novobarokní produkce, jež byla na jedné straně ovlivněná „,neklasickými příklady“ barokních sochařu Ferdinanda Maxmiliána Brokoffa a Matyáše Bernarda Brauna, ale na straně druhé také myslbekovským akademismem (spadajícím vlastně pod styl klasický). ${ }^{7}$

Všechny zmíněné osobnosti, promýšlející barokní hodnoty, pracují se základní proměnnou týkající se západního ratia. Z toho vyplývá, že cestu k uznání baroka otevřelo především směřování Evropy druhé poloviny 19. století, kdy v mnoha zemích vyvrcholila snaha o zesílení národní identity a docházelo k hospodářskému rozkvětu. Zatímco z Ra-

Kloučka, Ohmanna i Zeyera, vznikajících ke konci 19. století s cíleným účelem o propagaci hodnot tohoto stylu.

3 Srov. Ernest C. Hassold, The Baroque as a Concept of Art, College Art Journal VI, No. 1, Autumn 1946, s. 3-28 (4).

4 nn., „Barok-Bauten Wiens“/rec./, ZSAI XVIII, 1883, č. 2., s. 141

5 Viz Albert Ilg, Die Zukunft des Barockstils. Eine Kunstepistel (1880), Cornelius Gurlitt, Geschichte des Barockstiles und des Rococo in Deutschland (1889).

6 Srov. Heinrich Wölfflin, Renaissance und Barock: eine Untersuchung über Wesen und Entstehung des Barockstils in Italien, München 1888. - Viz též Heinrich Wölfflin, Renaissance and Baroque, Cornell University Press 1967. - William Egginton, The Theatre of Truth: The Ideology of (Neo)Baroque Aesthetics, Stanford University Press, 2009.

7 Viz Martina Bezoušková, České novobarokní sochařství, dizertační práce Ústavu pro dějiny umění FF UK, Praha 2019, s. 8-9. 
kouska zněl Ilgův apel k oživení slávy habsburské monarchie a opakovaným architektonickým vzorem v architektuře se stal Hofburg, ve Francii se novobaroko profilovalo svým dekorativním půvabem jako oficiální styl Napoleona III. V kontextu evropského dění nicméně české novobaroko přineslo svá společensko-kulturní specifika, která ovlivnila i jeho podobu.

V Čechách byla novobarokní exploze usnadněna projektem pražské asanace a s tím souvisejícím požadavkem malebnosti, kdy se v důsledku zachování rázu Prahy přistupovalo k volbě novobarokních fasád s odpovídající dekorativní sochařskou výzdobou. Zásadní úlohu měla v tomto ohledu vzorníková kompendia Celdy Kloučka a Friedricha Ohmanna, v nichž byly cíleně propagovány barokní motivy, které mladé umělecké generaci ukázaly možnosti stylové transformace. ${ }^{8}$ Klouček i Ohmann kolem sebe ke konci století soustředili okruh studentů z Uměleckoprůmyslové školy, s nimiž tento posun od historizujících slohů směrem k secesi (v rámci architektury a dekorativní plastiky) uskutečnili.

Z poněkud jiných pohnutek sestavil sbírku architektonických motivů Baroc a rococo (1895) Jan Zeyer, dlouholetý spolupracovník architekta Antonína Wiehla. Zatímco Klouček a Ohmann viděli v baroku určitý stylový potenciál, Zeyer chtěl především uchránit barokní architektonické stopy, které mohly být v rámci stavebního ruchu kolem pražské asanace nenávratně ztraceny. Zmíněné kompendium představuje na 100 listech motivy „ryzího baroka“, které Zeyer v zásadě pojal jako korektiv 19. století. „Podrobné a promyšlené studium jejich staveb poskytuje architektu tolik poučení a dává nahlédnouti vorganismus barokního slohu, v jeho ohebnost a schopnost přispiosobiti se v̌̌em požadavkům lehce, tou měrou, že nelze dosti odporučovati všem, kteři se zajímají o domácí památky naše, aby stavby ty nejen kreslili, nýbrž i podrobným měřním získali si o jich tvarech správného názoru, aby studium jich provádèli s toutéž láskou a di̊kladností, které jsou nezbytny ku vniknutí do pravé podstaty jakéhokoliv slohu. "

Pro rehabilitaci baroka v Čechách byly především důležité výstavy odehrávající v devadesátých letech 19. století, díky nimž se návštěvníci mohli lépe seznámit s jeho pozapomenutými estetickými kvalitami. Umělecké prezentace $\mathrm{v}$ rámci takto rozsáhlých výstav ale odrážely rozdílné výsledky práce, a to nejen z hlediska kvality, ale docházelo též na ideologické střety, k čemu by rehabilitované baroko mělo vlastně sloužit.

Přínos Zemské jubilejní výstavy (1891) tkvěl ve variabilitě barokního revivalu. Dekorativní polohu raného historismu zastupoval pomník Jiř́ho z Poděbrad (1891) od Bohuslava Schnircha. ${ }^{10}$ Myšlenka ke zbudování pomníku husitského krále rezonovala již

8 Celda Klouček, Ornamente für Architectur und Kunstgewerbe nach Plastischen Originalen von Celda Klouček, Frankfurt nad Mohanem 1888. - Celda Klouček, Návrhy umělecko-průmyslové a dekorativní, b. m. 1893. - Celda Klouček, Profesor C. K. umělecko-prưmyslové školy v Praze a jeho žáci, Vídeň 1906. - Friedrich Ohmann, Architektura a umělecký průmysl doby baroku, rokoka a empiru $v$ Čechách a jiných zemích rakouských, Vídeň 1896. - Friedrich Ohmann, Barock. Eine Sammlung von Plafonds, Cartouchen, Consolen, Gittern, Möbeln, Vasen, Öfen, Ornamenten, Interieurs etc., Wien 1897. - Friedrich Ohmann, V boji za moderní styl (1913), in: Jindřich Vybíral, Friedrich Ohmann, Praha 2013, s. 33.

9 Jan Zeyer, Baroc a rococo. Sbírka architektonických motivư, Vídeň 1895. - Viz též Rudolf Kříženecký, Kilián Ignác Dientzenhofer a clánkování architektonického letohrádku hr. Michny a praelatury u sv. Mikuláše na Starém Městě Pražském, Praha 1899, s. 1.

${ }^{10}$ Jezdecký pomník Jiř́ho z Poděbrad, vystavený na vysokém podstavci na Zemské jubilejní výstavě, setrval na svém místě jako solitér až do konání Národopisné výstavy českoslovanské (1895). 
v sedmdesátých letech 19. století, ale až následující desetiletí přineslo jeho pozvolnou realizaci. Pomník nezapře sochařovo mnichovské školení, které se v podobě teatrální monumentality a zaujetí pro detail názorně propsalo do stylového pojetí zakázky. ${ }^{11}$ Schnirchův dekorativní rámec historismu se však nestal v očích návštěvníků Zemské jubilejní výstavy znakem tvorby domácí provenience.

Sochař Celda Klouček zde prezentoval své novobarokní vázy z kufsteinského vápna, které byly zdobené dekorem s hrajícími si buclatými chlapci a stylizovanými květinovými motivy, a krb bohatě zdobený rokokovým dekorem. ${ }^{12}$ Ve spolupráci s Ohmannem a sochařem Vilímem Amortem dále připravil v rámci této výstavy koncepci Královského pavilonu ${ }^{13}$, jenž se stal jednou z prvních veřejně koncipovaných realizací v proklamativním novobaroku. ${ }^{14}$ Stále se ovšem nejednalo o novobarokní tendenci vzešlou z české umělecké tradice, forma bohatě zdobeného baldachýnu byla patrně zvolena jako symbol panovnické důstojnosti, možná s politickým nádechem všudypř́tomného Rakouska-Uherska. ${ }^{15}$ Pro pavilon bylo zvoleno vzorem oltářní ciborium se čtyřmi sloupy a na ně posazenými oblouky. Koncepce baldachýnu, užívaná od antiky přes baroko, patřila ve druhé polovině 19. století mezi časté prvky reprezentačních výstav a slavobrán. V českém prostředí se nicméně jednalo o ojedinělou ideologicky podbarvenou uměleckou manifestaci a novobarokní tendence přelomu století se posléze oprostily od výraznějších politických či mocenských konotací.

Pro čistou dekorativnost bílo-zlaté kombinace barokního dekoru sice označil glosátor Karel Matěj Čapek-Chod baldachýn jako chloubu výstavy, ale přínos jeho textů spočíval spíše v poukazu na slohový revival baroka. Návaznost na německé vzory se objevuje v reliéfu Nanebevzetí Panny Marie (c. 1891) od Vilíma Amorta, ${ }^{16}$ který svou měkce pojatou modelací značí cestu $\mathrm{k}$ naturalističtějším formám. Tento posun je patrný zejména při srovnání s reliéfem z náhrobku rodina lékárníka Klarnera (asi 1863) od Ludvíka Šimka, který na začátku šedesátých let 19. století prošel Mnichovem. Z obsahu prezentovaných uměleckých děl v rámci Zemské jubilejní výstavy vyplývá, že barokní revival měl v Čechách zpočátku podobné reprezentativní ambice spojené se svérázným naturalismem a teatrálností jako novobaroko německé provenience. Tento inspirační proud ale dosáhl prezentací v rámci této výstavy svého maximálního uměleckého přijetí. Od té doby se novobaroko opíralo takřka výhradně o českou tradici oživeného baroka. V rámci stejné výstavy byla prezentována Obět víry (1891) [obr. 1] od Ludvíka Wurzela, dodávající novobarokním př́kladům na komplexnosti znázorněnou pocitovou dynamikou, která dotváří tělesnou odevzdanost ukřižovaného připoutaného ke stromu. Př́klad této plastiky naznačil symbolistní vyznění pozdějších realizací kombinujících novobarokní ten-

11 Karel Boromejský Mádl, Umění včera a dnes, Praha 1908, s. 62, upozornil na návaznost na Schwanthalerovy jezdecké pomníky.

12 Výstava patřila po organizační stránce $\mathrm{k}$ nejnáročnějším projektům české architektury a rekapitulovala výtvarné hodnoty na ploše $300000 \mathrm{~m} 2$.

13 Jedná se o tzv. Kaiserpavillon, v dobových periodikách překládaný jako Královský pavilon, v současné literatuře spíše Císařrský. Viz Vybíral, Friedrich Ohmann (pozn. 8). Reprodukce v knize Ferdinand Fellner von Feldegg, Friedrich Ohmann's Entwürfe und ausgeführte Bauten, Vídeň 1906, s. 22.

14 Srov. nn.: Vilím Amort, Dílo II, 1904, č. 1, s. 266.

15 Vybíral, Friedrich Ohmann (pozn. 8), s. 55.

16 Karel Matěj Čapek-Chod se stal dvorním recenzentem Vilíma Amorta už na Zemské jubilejní výstavě (1891). Pozdější realizace na Schierově domě nás přesvědčují o úzkém propojení novobaroka s uměním 17. a 18. století. 
dence se symbolistní složkou, které vznikaly například v pojetí Quida Kociána (Jidáš, 1900-1904; Umélcovo věno, 1901) nebo Vojtěcha Šaffa (Neronova pochodeň, 1894).

Novobarokní tendence devadesátých let jsou stylově vícevrstevnaté a tematicky variabilní, přičemž pro jejich rozkvět byly důležité právě souhrnné výstavy tohoto desetiletí, poukazující nejen na zprůmyslnění českých zemí, ale také na dosavadní umělecký vývoj a tradice českého národa. Zdejší národní uvědomění bylo nejprve posíleno nalezením ikonických postav, a to nejen mezi historickými osobnostmi, ale také mezi žijícími umělci. Zásadní vliv na rozvoj raného historismu měl Bohuslav Schnirch, jenž se vedle bavorské neorenesance zaměřil také barokizujícím směrem. Velmi jasně to dokládá dílo Bojující Amazonky (1870) [obr. 2], bendlovsky cítěná Bakchantská scéna (1872) nebo brokoffovsky popisný fragment fontány (1891). Jeho naturalisticko-dekorativní tvorba ovšem ztratila při cestě k modernímu výrazu pro mladou sochařskou generaci na přitažlivosti. Příkladem hodným následování byl pro sochařství zvolen Josef Václav Myslbek, tvůrčí eklektik, jehož dílo ukázalo mladé generaci úctu k domácí tradici - kromě jiného také k českému baroku.

Ovlivněn francouzskými prŕklady, předal Myslbek generaci devadesátých let podněty pro novobarokní směřování, které posílila jeho návštěva Paříže v roce 1878. V Paříži upoutala sochařovu pozornost francouzská akademická produkce, založená na po staletí budované tradici zobrazování lidského těla. Posléze vyžadoval po svých kolezích, Hynaisovi a Brožíkovi, kteří pobývali ve Francii, aby mu posílali reprodukce nebo odlitky francouzských děl, aby takzvaně „něco odkoukal“17 Jeho syntéza, kterou představil v rámci objednávky na dekorativní plastiky v díle Stálost ve smýšlení pro vídeňský Parlament (1880-1884), uvěznila smyslovou tělesnost v klasicizujícím tvarosloví. Tento reprezentační typ zakázky odpovídal svou monumentalitou nejen charakteru honosné historizující architektury, ale také Myslbekovým vlastním sochařských představám.

Oproti výpravným a veskrze dekorativním francouzským plastikám se však Myslbek posléze pustil do využití naturalistické formy obohacené o práci s realistickými detaily a s nadsazením výrazové škály. ${ }^{18}$ Tento „,barokisující romantismus“ shledal Vojtěch Volavka už v raném Myslbekově díle Pelikáni, určeném na fasádu domu řezníka Pelikána v Chrudimi (1868); ${ }^{19}$ finální provedení ale spíše působí jako idealistická studie podle přírody. Pelikáni sice obsahují prvky malebné modelace, nikoliv barokní reminiscence. Novou orientaci lze lépe pozorovat na náhrobku Václava Švagrovského (1881-1883) ${ }^{20}$, který sochař začal koncipovat již před svou cestou do Paříže. Barokní výrazovost a dynamika je silně patrná na zakázce pro mostní sousoší pro Palackého most v Praze (1881-1885). Svými tématy čerpala z obraznosti památných Rukopisů, což vyhovovalo šírícím se nacionálním ideologiím a výsledné provedení přineslo Myslbekovi uznání. I když zakázka byla $\mathrm{z}$ hlediska významu a umělecké kvality hodnocena jako paralela k barokní galerii na Karlově mostěe, ${ }^{21}$ provedení sousoší bylo po dokončení kritizováno, že převedením

17 Petr Wittlich, České sochařství ve XX. století, Praha 1978, s. 15.

18 Václav Vilém Štech, Josef Václav Myslbek, Praha 1952, s. 23.

19 Vojtěch Volavka, České malírství a sochařství 19. století, Praha 1968, s. 62. - Podobně hovoří též V. V. Štech (pozn. 18), s. 37.

20 Náhrobek sochař dokončoval až po svém návratu. Finální dílo ukazuje vláčné pohyby, uvolnění záhybů draperie, jejíž záhyby jsou zde podané jak ve spádu, tak ve struktuře látky, čímž oživují obrys kompozice. Předlohy k Myslbekovu náhrobku lze najít na pařížském hřbitově Père Lachaise.

21 Petr Wittlich, Jan Štursa, Praha 2008, s. 21. 
do monumentálního rozměru ztratilo dynamičnost a odstředivou sílu kompozice, která byla patrná v soutěžních skicách. ${ }^{22} \mathrm{Na}$ pojetí mostních sousoší proporčním řešením a pohybem postav navázal Myslbekův žák Ladislav Šaloun ve svém prvním projektu na pomník Františka Palackého v Praze (1898). Šaloun tehdy ve spolupráci s Aloisem Dlabačem představil poměrně konzervativní pojetí s ústřredním obeliskem a centralizovanou skupinou, doplněnou o čtyři páry význačných postav z českých dějin, což se i po stránce obsahové slučovalo s Myslbekovým záměrem.

V pohybovém uvolnění následně Myslbek pokračoval při řešení některých raných návrhů sochy Hudba z let 1892-1894. Druhá verze této Myslbekovy věčné inspirace sice není dynamická, její výraz se ovšem plně oddává smyslovosti a vnitřním pocitům. Sochař následně uplatnil nově nalezenou citovost při řešení postav světic z pomníku svatého Václava (návrhy z let 1895-1897). Objem postav zdůraznil výraznou draperií, která se stává Myslbekovým oživujícím, byt’ stylizovaným prostředkem převzatým z domácí barokní tradice. U postavy sv. Anežky z kompozice svatováclavského pomníku např́íklad autor ukázal její prostorově akcentované cítění, které ale zároveň ztratilo na živosti záhybů.

Pohyblivost draperie Myslbek více rozvedl v pojetí pláště klečící sochy kardinála Bedřicha Schwarzenberga pro katedrálu sv. Víta (1892-1895). V př́ípadě tohoto díla se nejedná o doslovnou brokoffovskou nebo braunovskou citaci, nýbrž pouze o přejímání prvotních barokních impulsů. Šat kardinála Schwarzenberga spadává v mohutně cítěných, těžkých řasách dolů, přičemž teprve v zadní části je pojednán s akcentem k bohatším, živějším záhybům, které se vlní. Ačkoliv Myslbek pracoval podle fotografie, dodal záhybům vlastní umělecký záměr založený spíše na živosti než na monumentálně cítěném pojetí.

Dílo Josefa Václava Myslbeka vneslo do českého sochařství přelomu století eklektický ráz a navedlo mladou generaci sochařů k zájmu o národní odkaz i prosazení intimní citovosti. Občas se Myslbek dostal do polohy, kdy korigoval prŕlišnou dekorativnost střídmým realismem, umně uplatněným nejen v modelaci šatů, vlasů či kůže zobrazovaných postav, ale především v jeho portrétní tvorbě, v níž lze zároveň vypozorovat popisnost a baroknost provedení po plastické a citově-psychologické stránce. Myslbek, který většinou pracoval podle poskytnuté fotografie, vytvářel „poprsí plná energického, robustního života [která] mají větší vychovávající sílu, nežli celé řady traktátů. Neobjeví se asi tak hned portrétista sochař této intensity, ale nesmí být přehlédnuto, že poučení od něho vycházející, z jeho prací se vynořující, padají u mladších na půdu lačnou a úrodnou. "23

Na začátku stojí portréty osobností s rázně budovanými a do široka rozvedenými rysy tváře, busta Trojana nebo Podobizna Františka hraběte Thun-Hohensteina, na něž navazuje realisticky ztvárněná podobizna Vojtěcha Lanny s nakloněnou hlavou (1909). Thun-Hohensteinova podobizna sice představuje stojící postavu, nejedná se pouze o portrét. Její energeticky vychýlená hlava s mocně rozevlátými vlasy dodává celému znázornění potřebný dynamismus. ${ }^{24}$ Podobnému baroknímu rázu se citelně přiblížil sochař Vilím Amort, i když nebyl Myslbekovým žákem. Přivydělával si zhotovováním portrétů bohatých měštanů, přičemž nejzajímavější je v tomto ohledu poprsí Paní Pernerové (1899),

22 Srov. J. V. Myslbek, péčí a nákladem „Unie“, Volné směry VI, 1902, č. 3, 89-90.

23 Srov. M, Zpráva v sekci Výtvarné umění, Zlatá Praha XVI, č. 30, 2. 6. 1899, s. 358.

24 Sádrová verze Podobizny Františka hraběte Thun-Hohensteina byla vystavena na Zemské jubilejní výstavě v roce 1891, bronzový odlitek až na Rudolfinské výstavě v roce 1893. 
které ve své diplomové práci ztotožnila badatelka Andrea Svitáková podle fotografií z rodinné pozůstalosti. ${ }^{25}$ Největší pozornost zaujímá v provedení plášt, jehož boční kraje se rozprostírají široko do stran, což může mírně připomenout poprsí vzniklá v období baroka.

Po vzoru barokních hlav zřejmě Amort vytvořil také poprsí Nerudovo (1895), jehož finální provedení nakonec podlehlo schematizaci. Zřejmě za to mohla skutečnost, že sochař tenkrát pracoval podle fotografie. ${ }^{26}$ Amort rovněž vytvořil podobiznu Františka Ladislava Riegera (c. 1900), která vyniká svou plastickou modelací tváře, v níž se zračí moudrost a stáří zobrazovaného.

Myslbek je rovněž autorem Brokoffovy desky z ,Hopfenštokü“.27 V minulosti byl tento dům mylně pokládán za někdejší bydliště sochařské rodiny, což vyvrcholilo odhalením pamětní desky od Myslbeka, která byla kvůli chybnému určení domu později odstraněna. S ohledem na nabízející se propojení s barokem je zajímavé, že Myslbek nepojal desku v novobarokním duchu a její námět je zachycen stroze, bez přítomnosti historizující složky. Deska se stala vzorovým návratem k tradici, barokní i myslbekovské zároveň. ${ }^{28}$ Velkou měrou k tomu přispěly myšlenky sochaře Jana Štursy, bývalého Myslbekova žáka, nebo kritika Zdeňka Hlaváčka, že „,baroko a Myslbek jsou základy našeho plastického názoru' 29 a že určují další směřování českého sochařství. Toto tvrzení je však platné pouze omezeným způsobem.

Pravdou zůstává, že i když byla v souvislosti s Myslbekem často zmiňována jeho inspirace Brokoffem a Braunem, mistr nikdy plně nepodlehl baroknímu neklidu a vždy se vracel k zásadám pevně modelované figury, jejíž výraz byl prosycen intimní citovou složkou a pohyb se plasticky rozprostíral do prostoru. Znamená to, že barokní reminiscence (citovost a odstředivá pohyblivá síla) jsou v Myslbekově díle rozhodně přítomny, po formální stránce ale vítězila ona uzavřená kontura.

I přesto, že Myslbek dal k rozvoji novobarokních tendencí silný podnět, nezúčastnil se jejich hlavního projevu. Jeho žáci z Akademie výtvarných umění (Quido Kocián, Bohumil Kafka, Gustav Zoula, Jan Štursa a další) na svého učitele zdárně navázali, mnozí z nich novobarokní fázi pojali jako mezistupeň na cestě k moderním výrazovým polohám. Co do počtu novobarokních realizací byla plodnější větev konzervativnějších sochařu generace devadesátých let, kteří byli povětšinou spjati s realizacemi funerálních a veřejných pomníků nebo s dekorativní plastikou (Čeněk Vosmík, Luděk Wurzel, Antonín Procházka, Antonín Popp, Vilém Amort a Josef Mauder). Tito méně známí sochaři se snažili umělecky vyniknout na rudolfinských výstavách, pořádaných každoročně pražskou Krasoumnou jednotou, které dobře ilustrují variabilitu novobarokních

25 Pravděpodobně se jedná o podobiznu ženy rodinného lékaře K. Pernera, který byl dokonce svědkem na svatbě dcery Vilíma Amorta v roce 1909. Viz Andrea Svitáková, Sochař Vilím Amort, 1864-1913, diplomová práce Semináře dějin umění Filozofické fakulty Masarykovy univerzity, Brno 2012.

26 Srov. nn, Poprsí Nerudovo, Světozor XXIX, č. 46, 27. 9. 1895, s. 552.

27 Do boční fasády původního barokního domu byl zakomponován rozměrný portál se sochami pocházejícími pravděpodobně z dílny Brokoffü, který původně zdobil hlavní průčelí domu. Tento barokní dům je v současné době včleněn do funkcionalistické stavby situované na rohu Navrátilovy a Vodičkovy ulice v Praze.

28 V roce 1929, kdy byla uspořádána retrospektiva sochařova díla, bylo dokonce $\mathrm{v}$ dobovém tisku s lítostí poznamenáno, že tato deska, v současnosti hodnocená pouze jako okrajová část Myslbekova díla, nebyla vystavena.

29 Zdeněk Hlaváček, Situace českého sochařství, Volné směry XL, 1947-1948, s. 78-95 (91). 
tendencí a inspirační podněty, z nichž tito umělci vzešli. V jedné z recenzí výstavy bylo přitom poukázáno na těžkou situaci mladé sochařské generace, o jejíž tvorbu nebyl oproti malírství tak značný akviziční zájem a většina sochařů se uchylovala k portrétní nebo dekorativní tvorbě. ${ }^{30}$

V roce 1893 byla na výstavě Krasoumné jednoty vystavena díla Saturnus (č. kat. 731) a Audacius (č. kat. 730) od Gustava Zouly, Myslbekova žáka a generačního současníka Bohuslava Schnircha. Zmíněná plastika Saturnus ${ }^{31}$ [obr. 3] se vymyká Zoulově ostatní tvorbě, která je převážně „,myslbekovsky klasicistni“, a lze v ní najít „,barokní di̊myslnou eleganci“, a to zejména ve ztvárnění obou nohou, jedné stojné a druhé v nákroku. ${ }^{32}$ Podobný prvek byl typický pro raně a vrcholně barokní dřevořezby 17. a 18. století. Při pohledu na postoj Saturna okamžitě vyvstane na mysli analogie s dílem Arnošta Jana Heidelbergera a jemu připsanou postavou sv. Jana Křtitele z kostela Panny Marie Sněžné (kolem 1650). Inspiračním zdrojem mohly také být pozdější práce Matyáše Bernarda Brauna pro zámecký park v Lysé nad Labem (po 1730), kterým odpovídá i natočení hlavy Saturna. Barokní zpracování Zoula využil rovněž v rozpětí křídel a v pojetí ruky držící přesýpací hodiny či klepsydru. ${ }^{33}$ Zajímavou analogii můžeme vytvořit při srovnání $S a$ turna s dílem Chronos a Niobe od Lazara Widemanna (1740), které obsahuje braunovské i brokoffovské kořeny. Za inspirační zdroj mohla koneckonců posloužit také postava Brokoffova Chrona z náhrobku Václava Wratislava z Mitrovic (1714-1716). Srovnání všech tř́ děl ukazuje snahu Gustava Zouly převést barokní základ do takřka akademizující polohy, díky čemuž se z finálního provedení stává v porovnání s barokní předlohou schematická formule. Barokní reminiscence ve zpracování sochy reprezentují dobový zájem o expresivní stylové vybočení.

Sochař Zoula se rovněž pustil do zpracování biblického motivu Obět' Abrahamova (c. 1893) [obr. 4], kde znázornění Abrahamových vlasů a vousů jednoznačně nese barokní stopy. Ztepilá Abrahamova postava na sebe upoutává hlavní pozornost svým nádherně promodelovaným pláštěm, jehož sklady přispívají ke zvýraznění výšky stojící postavy. V provedení Abrahama se nezapře Zoulovo školení u Myslbeka, jak dokládá analogie s Myslbekovým návrhem na sousoši Lumír a Píseň pro Palackého most v Praze (1881). [obr. 5] Naopak pojetí Izáka žádné barokní reminiscence nenese, jeho klečící tělo je pečlivě modelované, byt’ v obličejové části lehce schematizované. Podobným způsobem se barokní rezidua propsala do přepadávající nohy ležící postavy v díle Kain a Ábel (1901)

30 M, Zpráva v sekci Výtvarné umění (pozn. 23), s. 370: „Nejsme zvyklí na Výročních výstavách Krasoumné jednoty hledati přehled nebo vrcholky roční úrody plastické. (...) Musí to být již zcela zvláštní interes, který českého sochaře pohne výstavu obeslati, ponejvíce jiný, aneb aspoň jinak zbarvený nežli u malíre. Tento i u nás má na výstavě jakous takous naději, že jeho obraz v nejlepším prípadě nalezne kupce, za to knihy prodeje plastik zuistávají po léta netknuty a jejich listy prázdny. Co príijde do výstavy, je podobizna juž objednaná nebo darovaná, několik dekorativnich plastik, rovněž pro určité budovy objednané; odváží-li se však český sochar podvoliti se vlastní tvořivé iniciativě, zajímá to několik jeho přátel, dočte se o tom v referátech, ale ani soukromníku, ani které korporaci nezableskne před tím žádost, prevevésti takovou práci ve svůj majetek. (...) Proto téměř všechny české plastiky zprvu neobjednané, $k$ nimž byl umělec puzen jen vlastním vnuknutím a vlastní touhou s predmètem své fantazie se vyrovnati, vracejí se do místa svého rodiště zpět a nejednou tam zacházejí v prachu a rozbitinách."

31 K. M. Čapek-Chod ještě ve svém stručném zhodnocení dodal, že originál sošky byl v majetku milovníka umění, právníka Josefa Stupeckého.

32 K. M. Č., Saturnus, Světozor XXVIII, č. 47, 6. 10. 1893, s. 564.

33 Klepsydra je předmět, jenž neměří denní čas, ale odměruje časový interval. Velmi dobře se to Zoulovi hodilo pro znázornění Saturna, římského boha zemědělství, sklizně a času. 
od Quida Kociána. ${ }^{34}$ Čapek vychválil dílčí barokní zpracování také u postavy sv. Petra od Ladislava Šalouna, který byl údajně vytvořen ve stylu, ,,jemuž je podrobena i pěkná barokní hlava - produkt hlubších studií, k nimž Praha poskytuje tolik vydatné príležitosti “35 Dílo, které mohlo být zamýšleno jako dekorativní plastika, se mi nepodařilo dohledat v žádné reprodukci, tudíž nelze posoudit objektivnost citace. Na druhou stranu Karel Matěj Čapek působil jako vytrvalý glosátor konzervativnější části mladé sochařské generace a jeho postř̌ehy většinou byly trefně mířené.

Barokní základ zpracovaný moderním způsobem a s technickou i modelační zdatností se mohl stát pro české sochaře výrazovým prostředkem, a tedy důležitým předstupněm k dalšímu stylovému vývoji, jak dokládají následující příklady.

Jakýsi přechodový moment na cestě k modernosti vystihuje tvorba Quida Kociána, talentovaného Myslbekova žáka, který se od svého vzoru pomalu odpoutával směrem k symbolismu. Z jeho tvorby je důležité zmínit dílo Cikánka (c. 1899), u něhož je patrná silná stylová vazba na mánesovský lyrismus zprostředkovaný právě Myslbekem, stejně jako návaznost na pohybovou dynamiku, kterou lze pozorovat u Myslbekových návrhů na mostní sousoší pro Palackého most (1881). Zřasení šatu Cikánky je energické, byt silně stylizované. K novobaroku se Kocián více přiblížil v dynamickém, monumentálně cítěném sousoší Pro vlast (1899), reprodukovaném na stránkách periodika Zlatá Praha. Kompozici vévodí gesta zobrazených postav, která se otevírají do prostoru, což na první pohled působí barokním dojmem. Pohyb nicméně nevychází z jádra kompozice, rozpohybovanost je pouze vnějším rysem. Dílo Pro vlast známe pouze jako sádrovou skicu, lze však předpokládat, že původně bylo zamýšleno jako dekorativní plastika.

Postoj Kociánovy sochy Jidáše (1900) lépe vyjadřuje novobarokní urputnost, v níž jsou tělo i látka zmítány odstředivou silou do prostoru. Pohyb postavy je jednoznačně motivován vnitřním myšlenkovým pnutím, podobně jako u Františka Bílka v plastice Vím (c. 1903) z cyklu Cesta, čímž překračuje meze pouhého výrazového znázornění. ${ }^{36}$ [obr. 6] Bílkovy sochy kombinují plošnost a prostorovost, která je zastoupena bud' gesty postav, nebo významem díla, jakousi vizí. „Pokouší se [Bílek - pozn. autorky], jinými slovy, svými postavami obsáhnouti čas, místo aby je budoval z prostoru a do prostoru zpět nevratně jako nové svébytné jednotky zamístovat. "37 U Kociána ovšem hraje větší úlohu psychologizující složka než samotný pohybový dynamismus, což ukazuje na směřování k později vytvořené plastice Umělcovo věno (1901). Význam shrbené karikované postavy svírající hudební nástroj přesahuje formální východiska myslbekovského základu a ukazuje vykročení směrem k symbolistním polohám, na jejichž vývoji se novobaroko podílelo. V pomyslné vývojové analogii následuje Somnambula (1906) Bohumila Kafky, vykazující stejné citové rysy a viditelnou barokní linku ve vyjádření pohybu. Podobným způsobem by mohla na proměňující se barokní linii navazovat Gutfreundova socha Při toaletě (1911) či Úzkost (1911-1912). Ve všech příkladech navíc hrálo důležitou roli světlo, nikoliv jako doplňkový prvek, ale jako plnohodnotný výtvarný i obsahový činitel.

34 Petr Wittlich, Česká secese, Praha 1985, s. 132.

35 K. M. Čapek, Umělecká výstava v Rudolfině, Světozor XXVIII, č. 32, 23. 6. 1893, s. 383.

36 Prvotní podoba díla Vím vznikla v kresbě už v roce 1897; Bílkův cyklus kreseb Cesta byl vydán Svazem československého studentstva pro postavení pomníku Mládív Praze v březnu 1909. Kresby, které byly zpracovány jako sochy, zpodobují plasticky pozemskou dráhu člověka na zemi, jak poznamenal Miloš Marten.

37 V. N., Kol padesátin Fr. Bílka, Volné směry XXII, 1923-1924, č. 1, s. 74-76. 
V tomto ohledu jednoznačně do popředí vystupuje významovost světla měnící se v Bílkově práci na obsahového činitele. Zatímco pro impresionisty byl zrakový dojem finálním stádiem světelného pojetí, umělci na přelomu století chápali světlo významově. $\mathrm{Na}$ Bílka mohly mít v tomto ohledu vliv dvě skutečnosti, jeho náboženské přesvědčení opírající se o Bibli a eseje Otokara Březiny, které byly otiskovány ve Volných směrech. $\mathrm{V}$ nich je řeč o dvojím světle, a to v souvislosti s tématem spánku: „Neviditelný svět prostupuje světlem viditelným. Svobodou snu zasahuje umění do výkladu věcí (...). Světlo, které rozlévá po věcech, je čistší a záhadnější než světlo našeho slunce; je druhou, duchovou stranou našeho světa. " 38 Bílek vyložil svou symboliku světla odkazem na ideu božského světla obsaženou v bibli a Březinova slova částečně přenesl do díla Ukřrižovaný (1897). V prvním desetiletí 20. století se pojetí Bílkova světla rozvinulo pod dojmem četby Julia Zeyera v hlubší osobní mytologii, jak popsal Petr Wittlich. Bílek často propojoval dřevo se světlem, materiálem, který světelné elementy absorbuje a nechá se jimi přetvářet. Poprvé je to patrné již v díle Golgota - hora lebek, v roce 1897 dále vytvořil reliéf Význam slova Madona nebo později uplatnil stejný přístup při práci na díle Ukřižovaný. Ve všech případech hraje světlo nejen výrazovou, ale též významovou roli, což jej posunulo z pouhé barokní inspirace do poloh moderního sochařství přelomu 19. a 20. století. Podobným způsobem bylo světlo důležitým výrazovým i významovým činitelem pro barokní návrat ve třicátých a čtyřicátých letech 20. století, kdy byla barokní predilekce v sochařství opět spojena hlavně s pochopením symbolické hodnoty světla, ale v poněkud odlišném smyslu, souvisejícím s krizí umění a dobovou kulturně-politickou situací.

František Bílek a jeho expresivně moralistický projev, prosycený pocitovou subjektivností, byl kromě Myslbekova vzoru silným podnětem pro rozmach novobarokních tendencí. To dokládá především dílo Obět víry (1891) od Ludvíka Wurzela, učitele na Uměleckoprůmyslové škole v Praze, které znázorňuje mučedníka připoutaného ke stromu a patří mezi jedno z nejzajímavějších děl novobarokních tendencí devadesátých let 19. století. Provedení díla se nevyznačuje pohybem, ale dynamikou pocitovou. Dílo bylo mimo jiné vystaveno na Zemské jubilejní výstavě v roce 1891 a již tehdy sklidilo veskrze kladné zhodnocení z pera K. B. Mádla. Ten v provedení Myslbekova talentovaného epigona dokonce viděl příslib nového směřování českého sochařství.

Dílo Obět víry lze porovnat s Amortovou Kalvárií (c. 1899), pro niž sochař v průběhu hledání ideální kompozice vytvořil několik studií k hlavě Krista. Na základě jejich podob můžeme zřetelně sledovat stylově expresivní vývoj, proti němuž vystoupí intimnost Wurzelova pojetí ještě zřetelněji. Jednu ze studií Kristovy hlavy pojal Amort plně ve službách výrazu, patrně po vzoru Bílka. Zajímavostí také zůstává, že model byl o něco naturalističtější a více moderní oproti výslednému provedení.

Nejdůslednější barokní interpretaci navazující na Schnirchovu dekorativní linii předvedl sochař Josef Strachovský ze starší generace. Ačkoliv se věnoval převážně náboženské plastice, vytvořil na začátku svého mnichovského působení dílo Král Lear (1874). ${ }^{39}$

38 Wittlich, České sochařství ve XX. století (pozn. 17), s. 44.

39 Schnirch se začal školit u řezbáŕe Jana Káše v Praze (c. 1872), poté v Mayerově ústavu pro církevní sochy a dále na akademii v Mnichově pod vedením profesora náboženské plastiky Josefa Knabla (od 1874). Pracoval rovněž v dílně českého sochaře / kameníka Melnického, v níž dožívala z českého baroka vycházející rodinná dílenská tradice, na úkolech plastické dekorace architektur. Srov. Tatána Petrasová - Roman Prahl, Mnichov-Praha: Výtvarné umění mezi tradicí a modernou, Praha 2012, s. 244 . 
[obr. 7] Strnulost dramatické postavy je přebíjena exaltovaným prohnutím těla, které rozmáchlým gestem zvednuté ruky a vlajícími vlasy a vousy připomíná Braunovu postavu sv. Judy Tadeáše (1712). Důležitou roli hrál teatrální postoj, který se stane stěžejní náplní Strachovského pozdějších děl, například pomníku Karla Havlička Borovského v Kutné Hoře (před 1883).

Kolem roku 1893 vymodeloval sochař dílo Bořivojův křest, v němž dominuje do široka rozložená draperie a pyramidální kompozice postav. Dalším náboženským námětem je Strachovského dílo Ježíš přitel dítek (počátek devadesátých let 19. století), které ovšem nespadá do kategorie volné sochy, nebot’ bylo určeno k výzdobě průčelí nové školní budovy u sv. Ducha v Praze. Když ovšem porovnáme Strachovského dílo se stejným námětem od Vojtěcha Šaffa, vidíme určitý výrazový posun. V Šaffově díle Nechte maličkých ke mně přijíti! (c. 1890) probíhá vroucná komunikace mezi postavami, gesto Krista je dále vedeno mimo hlavní prostor sousoší, díky čemuž ztvárnění působí přirozeněji. Obě zmíněná díla s náboženským obsahem od Josefa Strachovského zastupují jakousi strnulou teatrálnost, jejíž dekorativnost a plasticita detailů zvítězily nad exaltací raného Krále Leara a dosáhly svého výrazového vrcholu právě v devadesátých letech 19. století.

Na výstavě Krasoumné jednoty v roce 1893 byl vystaven pohybově ztvárněný biblický motiv zpracovaný Vojtěchem Šaffem, a to s podobným sklonem ke statické teatralitě. Jedná se o sousoší Vraždění nemluvňat ${ }^{40}$ (před rokem 1893), v němž matka zoufale chrání své dítě ,p pred brutálním hmatem katana, u jehož nohou se svijí [postava matky poznámka autorky] vylíčena sousoším Šaffovým opravdu velmi presvědčivě a s veškerým pathosem, stupňovaným ještě neobyčejnou silou komposice“.41 [obr. 8] Technická úroveň díla a provedení jsou skutečně barokně působivé, i když pojaté s lehkou schematizující manýrou 19. století. Poměrně jasným zdrojem pohybového rejstříku se zdají být postavy zápasících Herkulů, všudypřítomných plastik pražských barokních zahrad. Z mnoha př́kladů, které by mohly být zmíněny, je kvalitní ukázkou Herkules s Kerberem (c. 1710) z bývalé Kolowratské zahrady od Ferdinanda M. Brokoffa. Podobný postoj se širokým nakročením a rotačním stočením funguje také v případě staršího Bendlova sousoší Anděla s dáblem (1650). Oproti barokním př́kladům však Šaffovo dílo působí jako zastavené $\mathrm{v}$ čase - zastavené v momentě nejpůsobivějšího pohybového vypětí, jehož vyznění se ale ztrácí v pomyslném naaranžování postav.

Podobným zpo̊sobem bylo pojato další Šaffovo dílo, hřmotné statické sousoší Ecce Homo (c. 1892), jehož působivost je založena na kontrastu mezi oběma znázorněnými postavami. Kristus a žoldnéř jsou prezentováni jako protiklady aktivní a pasivní figury, čemuž odpovídají jak jejich postoje, tak výrazová škála. Obě zmíněná díla od Vojtěcha Šaffa se stejně jako v prrípadě Gustava Zouly vymykají sochařově další produkci, která byla inspirována především římskou tvorbou a nesla znaky lyrické až niterné citové modelace. Tato ladná poloha převažuje v Šaffově tvorbě plaket a reliéfü, ale propíjí se též do sochařovy volné sochy.

Rozvoj novobaroka zpočátku zcela závisel na uznání hodnot výrazově bohatého baroka, ale jen co se jeho možnosti odpoutaly od historizujících poloh dekorativní plastiky, začal být vývoj této stylové tendence v Čechách svébytný, stojící na třech pilírích

40 Vystaveno na výstavě Krasoumné jednoty v Rudolfinu 1893 (č. kat. 717).

${ }^{41}$ K. M. Čapek, Umělecká výstava v Rudolfině X (pozn. 35), s. 382-383. 
českého sochařství, kterými byli Bohuslav Schnirch, Josef Václav Myslbek a František Bílek. Okruh novobarokních realizací ve volné soše se tak nezakládá pouze na Myslbekově smyslném akademismu, ale ovlivnil jej také mnichovský proud raného historismu plný dekorativnosti, který již v sedmdesátých letech předvedl Bohuslav Schnirch, absolvent mnichovské Akademie. Na jeho teatrální, v prostoru a čase strnulé pohyby zobrazených postav (Bojující Amazonky, 1870) nejlépe navázal Josef Strachovský, jehož Král Lear vystupňoval dramatický účinek teatrality do maximální míry. V akademicky orientované tvorbě Bohuslava Schnircha se však objevují díla, která nesou viditelné znaky barokního revivalu domácí provenience a která ukazují, že mu česká tradice nebyla lhostejná. Jedná se zejména o Schnirchovu práci Bakchantská scéna (1872) nebo fragment fontány (1891). Schnirch se v devadesátých letech i přes vzájemnou rivalitu nechal ovlivnit Myslbekovým pojetím náhrobku Švagrovského, jenž se v kombinaci $s$ francouzskou akademickou produkcí stal pro něj novým impulsem. Sochař využil kombinace dekorativního ladění s naturalizující složkou při ztvárnění pomníku Julia Grégra na Olšanech (1898). Původní sochařská výzdoba pomníku byla vytvořena podle návrhu architekta Kříženeckého. Z něho vyplývá, že Schnirch postavu oproti návrhu více stylizoval a změnil náklon jejího těla směrem k divákovi. Dílo Bohuslava Schnircha se v sedmdesátých letech nacházelo pouze na začátku novobarokního směřování, $\mathrm{v}$ devadesátých letech už ale cíleně využívalo baroknosti pro docílení iluzionismu, malebnosti a teatrálního účinku (Model trig pro Národní divadlo, c. 1881; fragment fontány, 1891; pomník Julia Grégra na Olšanech, 1898).

Ačkoliv dekorativně laděná Schnirchova tvorba byla velmi záhy považována za nepůvodní a zdobné historizující slohy byly modernistickými teoretiky odsouzeny za reakčnost, nevyhnula se ani novobaroku jistá stylizace. Sílící potřeba dekorativního cítění jej později v rámci dekorativní plastiky „přetavila“ v secesi. Tento stylový posun se odehrál v prostředí Uměleckoprůmyslové školy, a sice pod vlivem vzorníků Friedricha Ohmanna a Celdy Kloučka, zmíněných na začátku textu.

České novobaroko odráží ve své vícevrstevnatosti mnohé stylové tendence devadesátých let 19. století. Důležitým tematickým činitelem se stalo náboženství, případně odkazy k lokální mytologii, které souvisely s probíhajícím řešením národní otázky. Obojí je patrné v obsahu výstav Krasoumné jednoty, jejichž obsah se po roce 1839 tímto směrem orientoval. $\mathrm{V}$ devadesátých letech přinesly výstavy Krasoumné jednoty nejvíce novobarokních realizací, byt's určitými kvalitativními výkyvy. Velká část děl vystavovaných v devadesátých letech měla bud' námět alegorický (platilo především pro dekorativní plastiky, na výstavách rovněž prezentované), historický, nebo náboženský. ${ }^{42}$ Četné zastoupení náboženských námětů může být vysvětlováno jako historický přístup odeznívajícího romantismu, jehož dramatickému výrazu novobarokní tendence př́mo konvenovaly nejen svými výrazovými možnostmi, ale také stylovým pojetím odvozeným ze silně nábožensky orientovaného baroka. Velmi zaníceným propagátorem náboženství v té nejryzejší podobě byl též František Bílek, jehož vliv na mladou sochařskou generaci nelze rozporovat, o čemž svědčí především mistrovsky modelované dílo Ladislava Šalouna Ve stínu smrti (c. 1901). [obr. 9]

42 Po polovině devadesátých let 19. století ještě přibývají do žánrových kategorií národnostně až folklórně orientované motivy, a to zejména pod dojmem Národopisné výstavy českoslovanské (1895). 
Na konci století se odehrála rychlá stylová proměna, jak dokazuje hodnocení návrhu Palackého pomníku od Stanislava Suchardy. ${ }^{43}$ Krátce po smrti Františka Palackého bylo rozhodnuto o zbudování pražského pomníku. Po prvním kole soutěže na přelomu let 1897 a 1898 byl oceněn projekt Stanislava Suchardy a Aloise Dryáka, jehož dynamické kompozici dominovala rozevřená exedra s dvojicí krajních pylonů, jimž byly předsazeny barokizující skupiny Pohanství a Husitství. Ve středu kompozice se nacházela postava Františka Palackého. Dynamické, byt’ silně dekorativně laděné byly ostatně i reliéfy výjevů z českých dějin na zadní straně monumentu. Některé z nich Sucharda posléze zpracoval jako samostatné plakety. Právě zadní strana se stala jediným prvkem, který porota ve složení Myslbek - Mauder - Schnirch zkritizovala a nazvala jej „,velkým balastem“, což ukazuje, že se vưči novobarokním tendencím začala vymezovat i generace, která k jejich vzniku dala podněty. ${ }^{44}$

Z výše zmíněného vyplývá, že novobaroko značilo jen krátkou kapitolu. Jeho význam je ale pro vývoj českého sochařství větší, než se doposud předpokládalo. Novobaroko v českém sochařství 19. století neznamená pouze další barokní návrat v intencích myšlenek Heinricha Wölfflina a Vojtěcha Birnbauma, ${ }^{45}$ ale ve volné soše se jedná se o expresivní stylové přemostění od dobového naturalismu k symbolismu. Novobaroko užité ve volné soše bylo jen jednou z možností, jak naplnit dobovou touhu po moderním výrazu. Ideální plastikou v tomto ohledu je Jidáš (1900) od Quida Kociána [obr. 10], v němž se vzdělání u Myslbeka spojilo s výrazově bohatými možnostmi závěru 19. století.

\section{SUMMARY}

\section{Neo-Baroque and the Generation of Czech Sculptors of the 1890s}

Still an unexplored topic of this article presents Czech Neo-Baroque sculpture not only as a historicizing style, but as a style-expressive tendency as well. Progressive Neo-Baroque development became more significant once it separated itself from decorative sculpture. It followed up on the domestic traditions of 17 th and 18th century and built on the work of three sculptors - Bohuslav Schnirch, Josef Václav Myslbek and František Bílek. The notion of a national myth not only gave the younger generation an ideological basis but also a solid thematic and stylist foundation in line with versatile Neo-Baroque sculpture. This conservative tendency is apparent in the content of Art Union's exhibitions, which hosted pieces of lesser-known sculptors such as Gustav Zoula or Vojtěch Šaff. While some artists of the 1980s were more impacted by Myslbek's Academism and tended to rather conservatively cling to the vision of local inspirational sources, the others were actively transforming the principals of space layout as well as facial expressiveness, which took them to the edge of the cosmopolitan 20th century.

43 Viz Zdeněk Wirth, Návrh na úpravu náměstí Palackého, Styl I, 1908-1909, s. 59.

44 J. K.: Soutěž na pomník Palackého. Část 2, Národní listy XXXVIII, č. 157, 9. 6. 1898, s. 9 - příloha. Srov. Kateřina Kuthanová - Hana Svatošová, Metamorfózy. Pražské pomníky 19. století (katalog výstavy), Praha 2013.

45 Vojtěch Birnbaum, Barokní princip v dějinách architektury, Praha 1941. 
For the reasons mentioned above, Neo-Baroque in the Czech sculpture meant more than a mere Baroque revival of Wölfflin's theory. In the context of free-standing sculpture, it meant an expressive stylistic bridge from naturalism towards symbolism. Ideal sculpture in this regard is Jidáš (1900) by Quido Kocián. It reflects Myslbek's education combined with rich expressive varieties of the end of the 19th century. Another example is the piece Ve Stínu smrti (c. 1901) by Stanislav Sucharda which connects Bílek's sense for drama with decorative stylization. Both oeuvres show us that Czech Neo-Baroque used in free-standing sculpture was only one of the paths leading towards 20th century modernity.

\section{VÝBĚROVÁ BIBLIOGRAFIE}

Martina Bezoušková, České novobarokní sochařství (disertační práce, Ústav pro dějiny umění, FF UK), Praha 2019.

Vojtěch Birnbaum, Barokní princip v dějinách architektury, Praha 1941.

William Egginton, The Theatre of Truth. The Ideology of (Neo)Baroque Aesthetics, Stanford University Press 2009.

Ernest C. Hassold, The Baroque as a Concept of Art, College Art Journal VI, 1946, No. 1, Autumn, s. 3-28.

Celda Klouček, Ornamente für Architectur und Kunstgewerbe nach Plastischen Originalen von Celda Klouček, Frankfurt nad Mohanem 1888.

Celda Klouček, Návrhy umělecko-prưmyslové a dekorativní, 1893.

Kateřina Kuthanová - Hana Svatošová (eds.), Metamorfózy. Pražské pomníky 19. století (kat. výst.), Praha 2013.

Friedrich Ohmann, Barock. Eine Sammlung von Plafonds, Cartouchen, Consolen, Gittern, Möbeln, Vasen, Öfen, Ornamenten, Interieurs etc., Wien 1897.

Tatána Petrasová - Roman Prahl, Mnichov-Praha: Výtvarné umění mezi tradicí a modernou, Praha 2012.

Andrea Svitáková, Sochař Vilím Amort, 1864-1913 (diplomová práce, Filozofická fakulta Masarykovy univerzity v Brně), Brno 2012.

Vojtěch Volavka, V., Josef Václav Myslbek, Praha, V. Neubert 1942.

Vojtěch Volavka, České malírství a sochařství 19. století, Praha 1968.

Jindřich Vybíral, Friedrich Ohmann. Objev baroku a počátky moderní architekturyv Čechách, Praha 2013.

Petr Wittlich, České sochařství ve XX. století, Praha 1978.

Petr Wittlich, Česká secese, Praha 1985.

Petr Wittlich, Jan Štursa, Praha 2008.

Heinrich Wölfflin, Renaissance and Baroque, Cornell University Press 1967.

Jan Zeyer, Baroc a rococo. Sbirka architektonických motivů, Vídeň 1895. 


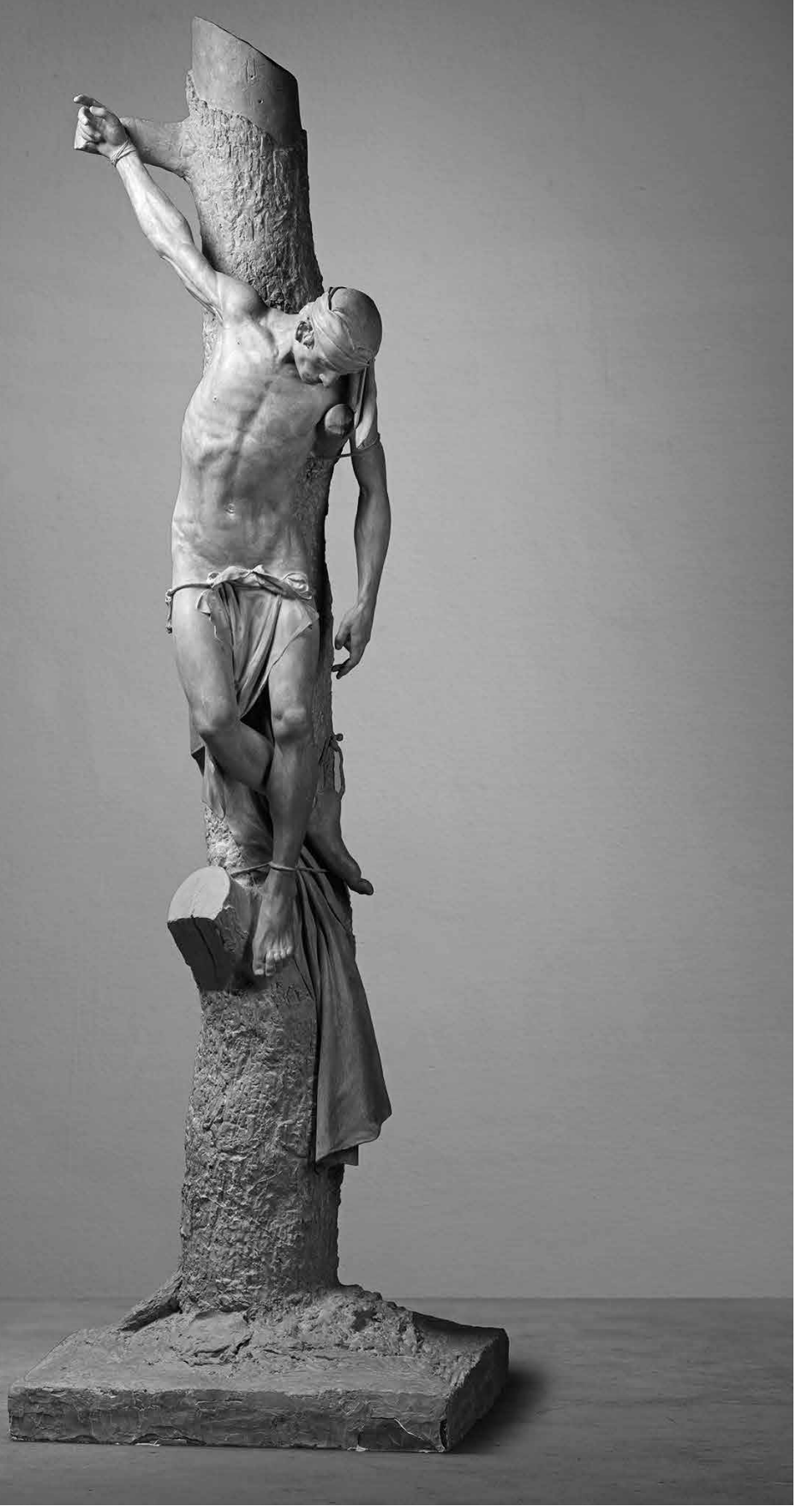

Obrázek 1. Ludvík Wurzel, Obět víry, sádra, 1891, Národní galerie Praha, inv. č. P20.

Fotografie (C) Národní galerie Praha 2021 

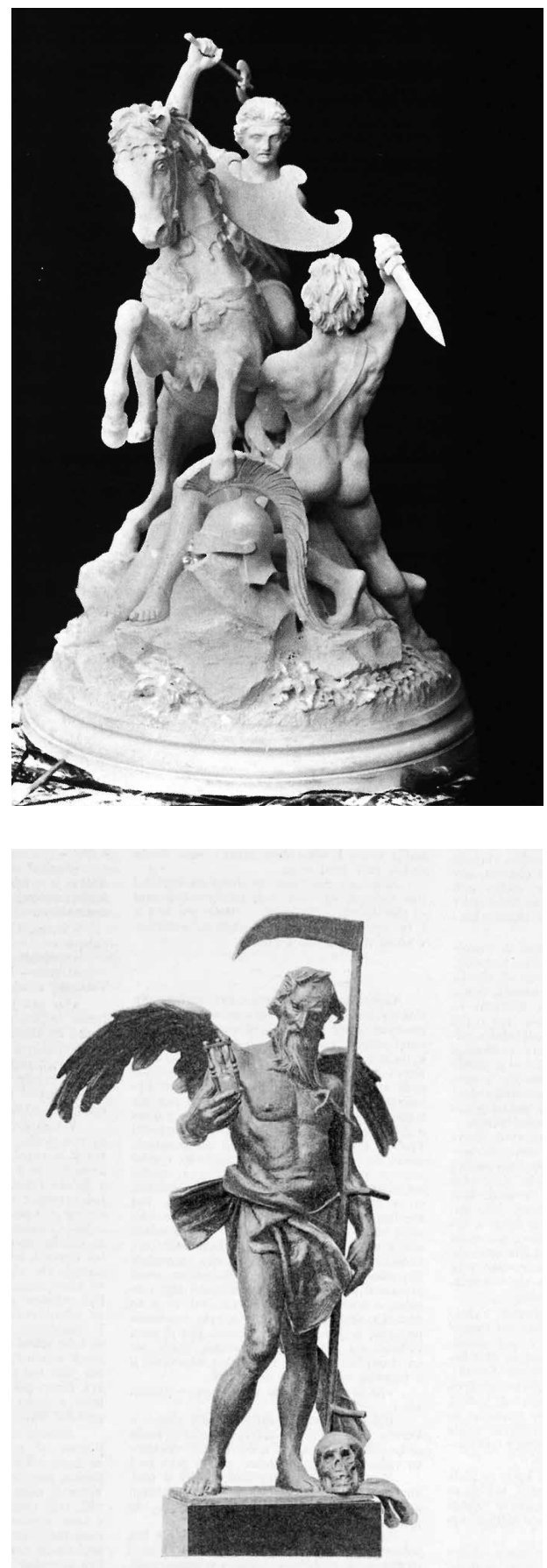

Obrázek 2. Bohuslav Schnirch, Bojující Amazon$k y, 1870$. Reprodukce z knihy Tatána Petrasová Roman Prahl (eds), Mnichov-Praha: Výtvarné umění mezi tradicí a modernou, Academia, Praha 2012, s. 244. obr. 88.

Fotografie () Národní galerie 2021

Obrázek 3. Gustav Zoula, Saturnus, c. 1893. Reprodukce z časopisu Světozor XXVII, č. 47, 6. 10. 1893, s. 553.

Fotografie (c) Národní galerie Praha 2021 

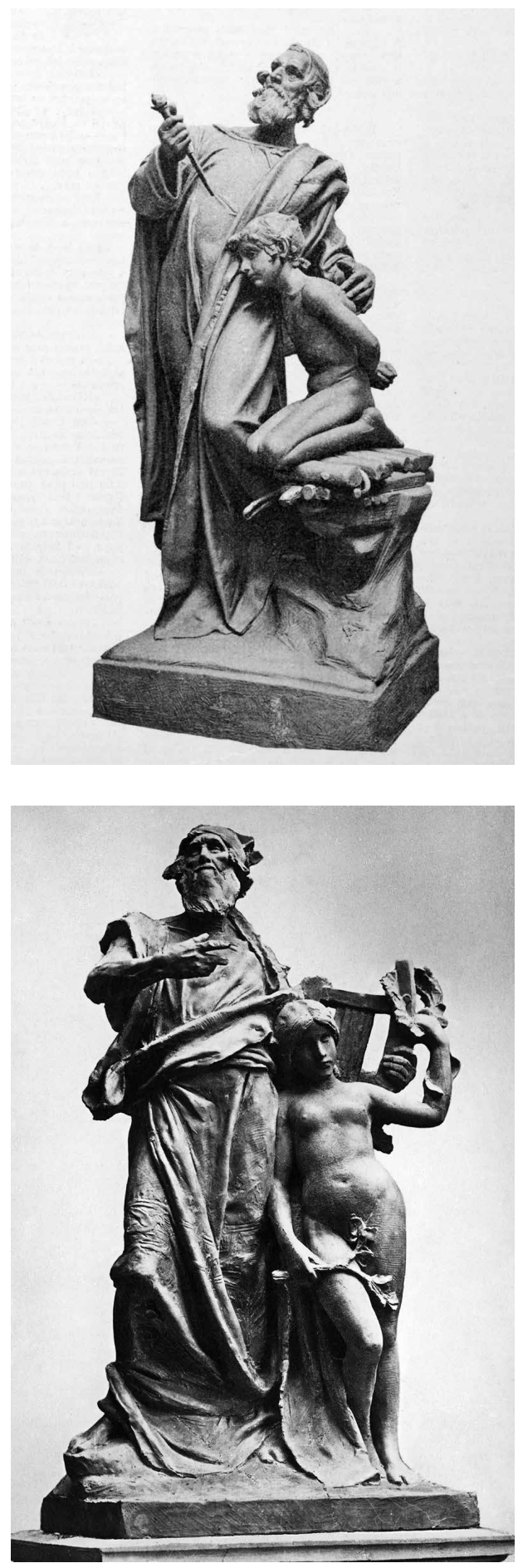

Obrázek 4. Gustav Zoula, Obět Abrahámova, c. 1893. Reprodukce z časopisu Svétozor XXVIII, č. $9,12.1 .1894$, s. 104.

Fotografie @ Národní galerie Praha 2021
Obrázek 5. Josef Václav Myslbek, Lumír a Píseñ, 1881, návrh ke skupině pro most Palackého, Praha. Archiv Národní galerie v Praze, fond Josef Václav Myslbek (1848-1922), Fotografie díla, přír. č. 4082, kart. 11 . 

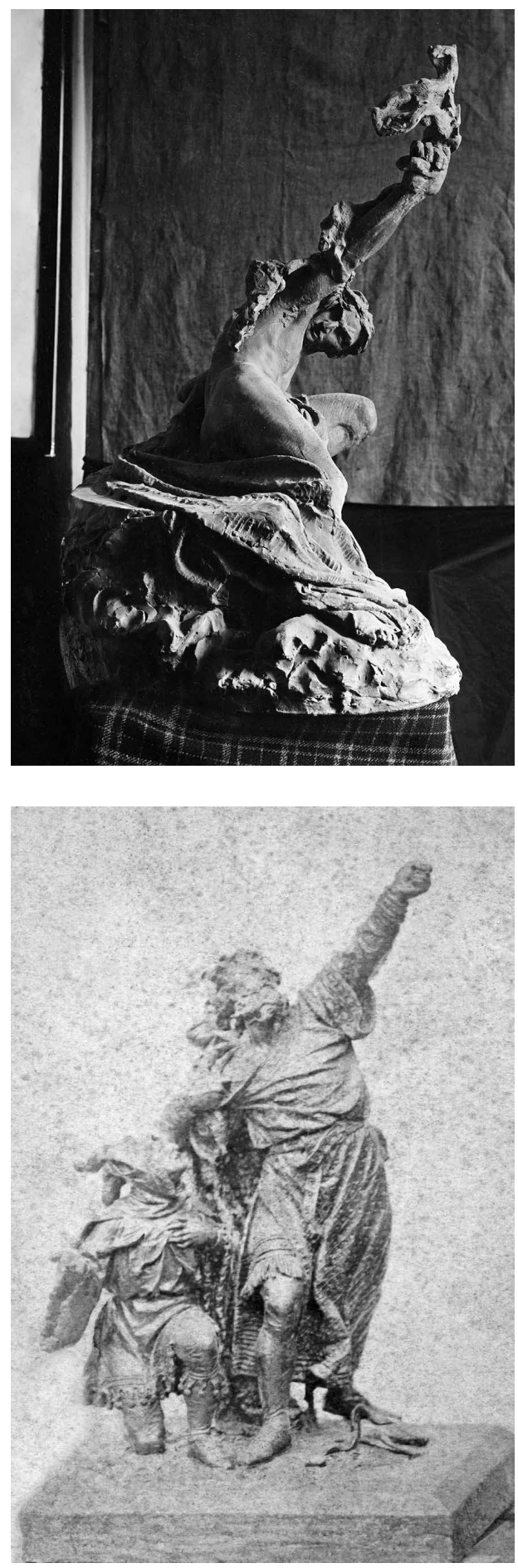

Obrázek 6. František Bílek, Vím, patinovaná sádra, 1903. Archiv Národní galerie v Praze, fond František Bílek (1872-1941), Fotografie díla, přír. č. 4184 .
Obrázek 7. Josef Strachovský, Král Lear, nedatovaná skica. Archiv Národní galerie v Praze, fond Josef Strachovský (1850-1913), č. 64, Fotografie díla, prrír. č. 2919. 

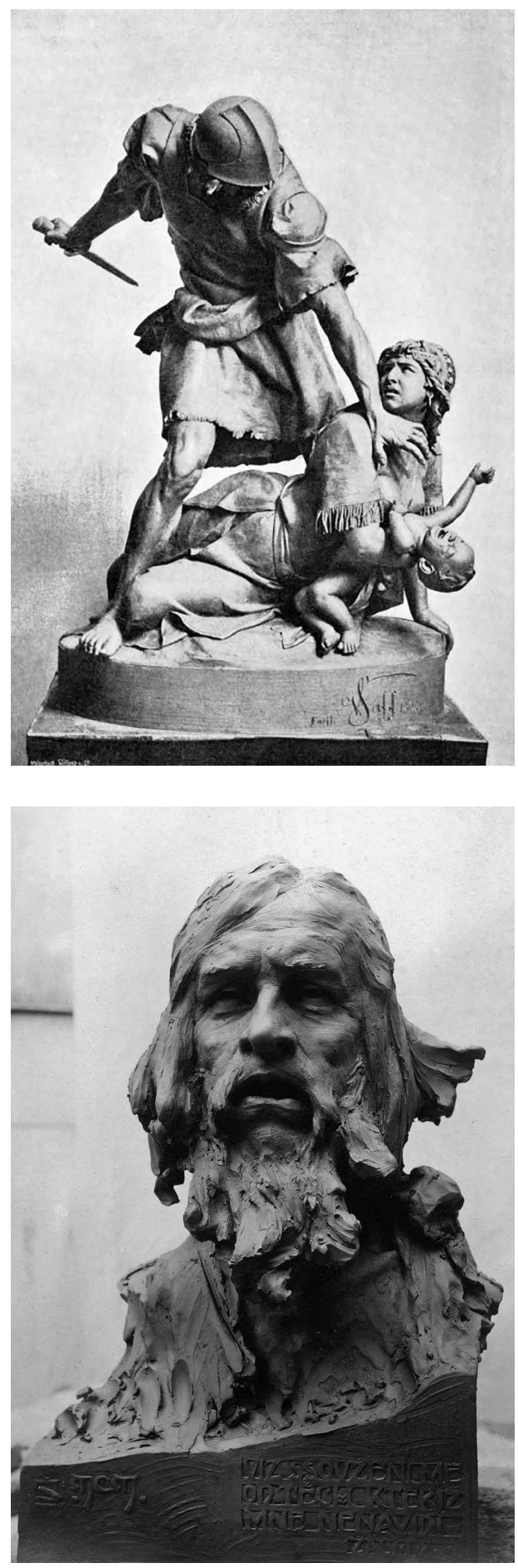

Obrázek 8. Vojtěch Šaff, Vraždění nemluvňat, před rokem 1893. Reprodukce z časopisu Zlatá Praha X, č. 23, 21. 4. 1893, s. 273.

Fotografie @ Národní galerie Praha, 2021
Obrázek 9. Ladislav Šaloun, Ve stínu smrti, c. 1901. Archiv Národní galerie v Praze, fond Ladislav Šaloun (1870-1946), přír. č. 4084. 


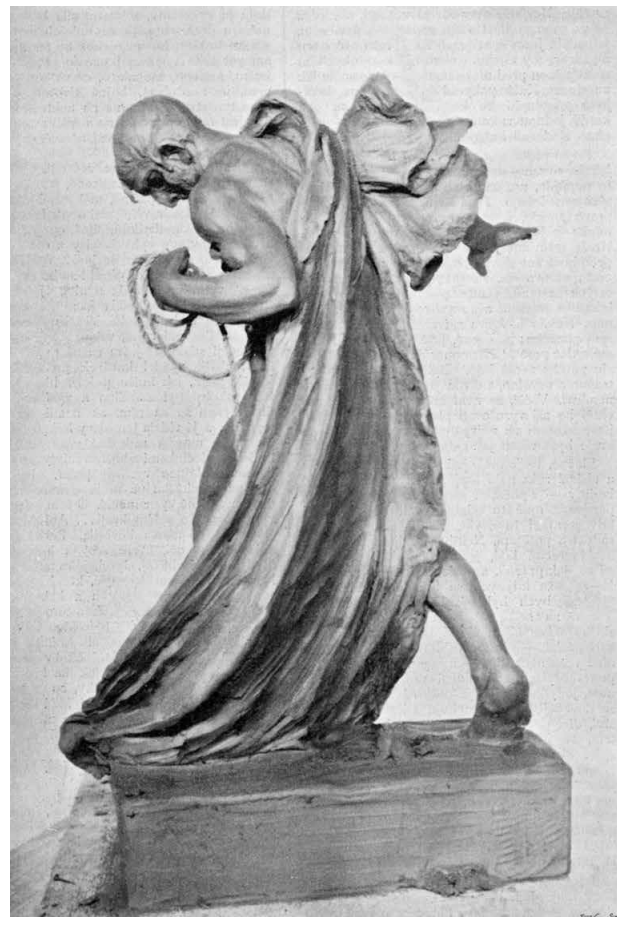

Obrázek 10. Quido Kocián, Jidáš, první skica, sádra, 1900. Reprodukce z časopisu Zlatá Praha XVII, č. 26, 4. 5. 1900, s. 304. Fotografie @ C Národní galerie Praha 2021 